\title{
Article \\ Methanol Steam Reforming on Bimetallic Catalysts Based on In and Nb Doped Titania or Zirconia: A Support Effect
}

\author{
Alexandra Lytkina-Payen ${ }^{1}$, Natalya Tabachkova ${ }^{2,3}$ and Andrey Yaroslavtsev ${ }^{1,4, *(D)}$ \\ 1 A.V. Topchiev Institute of Petrochemical Synthesis, Russian Academy of Sciences, Leninsky Prospect 29, \\ 119991 Moscow, Russia; lytkinapayen@gmail.com \\ 2 National University of Sciences and Technology "MISIS", Leninskiy Ave. 4, 119049 Moscow, Russia; \\ ntabachkova@misis.ru \\ 3 Prokhorov General Physics Institute of the Russian Academy of Sciences, Vavilov str. 38, \\ 119991 Moscow, Russia \\ 4 N.S. Kurnakov Institute of General and Inorganic Chemistry, Russian Academy of Sciences, Leninsky \\ Prospect 31, 119991 Moscow, Russia \\ * Correspondence: yaroslav@igic.ras.ru; Tel.: +7-9104812220
}

check for updates

Citation: Lytkina-Payen, A.; Tabachkova, N.; Yaroslavtsev, A. Methanol Steam Reforming on Bimetallic Catalysts Based on In and $\mathrm{Nb}$ Doped Titania or Zirconia: A Support Effect. Processes 2022, 10, 19. https://doi.org/10.3390/pr10010019

Academic Editor: Pietro Bartocci

Received: 24 November 2021

Accepted: 21 December 2021

Published: 24 December 2021

Publisher's Note: MDPI stays neutral with regard to jurisdictional claims in published maps and institutional affiliations.

Copyright: (C) 2021 by the authors. Licensee MDPI, Basel, Switzerland. This article is an open access article distributed under the terms and conditions of the Creative Commons Attribution (CC BY) license (https:// creativecommons.org/licenses/by/ $4.0 /)$.

\begin{abstract}
Methanol steam reforming (MSR) is considered an effective method for hydrogen storage and to generate high-quality hydrogen for fuel cells. In this work, a comprehensive investigation of the methanol steam reforming process using a bimetallic $\mathrm{Pt}-\mathrm{Rh}$ and $\mathrm{Cu}-\mathrm{Ni}$ based on different oxide supports is presented. Highly dispersed titania and zirconia doped with indium and niobium ions were synthesized by sol-gel method. The effect of the nature and quantity of the dopant cation $(\mathrm{In}, \mathrm{Nb})$ on the catalytic performance of titania supported metal catalysts was investigated. The conclusions obtained show a significant effect of both the metal alloy and the oxide support nature on the activity and selectivity of the methanol steam reforming process. Pt-Rh alloy catalyst shows higher hydrogen yield, but its selectivity in the MSR process is lower than for the catalysts containing the $\mathrm{Cu}_{0.8}-\mathrm{Ni}_{0.2}$ alloy. Heterovalent indium doping of titania leads to the catalytic activity increase. It was suggested that this is due to the defects formation in the oxygen $\mathrm{TiO}_{2}$ sublattice. On the contrary, the use of niobium oxide as a dopant decreases the catalyst activity in the methanol steam reforming process but leads to the selectivity increase in the studied process.
\end{abstract}

Keywords: hydrogen production; methanol steam reforming; bimetallic catalyst; doped titania; support effect

\section{Introduction}

Due to the contemporary worldwide trend to decrease environmental pollution levels, hydrogen energy receives a great deal of attention [1,2]. Since hydrogen in nature is always bounded, one of the key issues is its production. Over recent years, the focus has been on hydrogen production by natural gas steam reforming [3-5]. However, at the same time, carbon monoxide is formed, which is a catalytic poison for the low-temperature fuel cells [6,7]. Natural gas pyrolysis can be an alternative approach, which has the merit of almost absence a "carbon footprint" [8-11]. However, even in a catalyst presence, the process proceeds only at high temperatures and is accompanied by catalyst deactivation due to carbon deposits [9,12-14]. High energy consumption, a loss of significant energy partly due to the carbon exclusion from oxidation processes and a lack of demand for the producing carbon inhibits widespread occurrence of this process $[8,11]$.

The possibility of hydrogen production by light alcohols steam reforming is also of considerable interest. It should be noted that the interest in this approach is also motivated by the possibility of alcohols being obtained from biomass [15]. A considerable advantage is the significantly lower alcohol steam reforming process temperature. Even the catalytic reforming of ethanol proceeds at the temperatures of $400-500{ }^{\circ} \mathrm{C}$ [16]. In case of methanol 
stream reforming (MSR), the process temperature is usually $300-400{ }^{\circ} \mathrm{C}$. At the same time, MSR can proceed in two directions:

$$
\begin{gathered}
\mathrm{CH}_{3} \mathrm{OH}+\mathrm{H}_{2} \mathrm{O} \leftrightarrow \mathrm{CO}_{2}+3 \mathrm{H}_{2}, \quad \Delta \mathrm{H}^{0} 298 \mathrm{~K}=49.7 \mathrm{~kJ} / \mathrm{mol} \\
\mathrm{CH}_{3} \mathrm{OH} \leftrightarrow \mathrm{CO}+2 \mathrm{H}_{2}, \quad \Delta \mathrm{H}^{0}{ }_{298} \mathrm{~K}=90.2 \mathrm{~kJ} / \mathrm{mol} .
\end{gathered}
$$

In accordance with thermodynamics, reaction (1) dominates at low temperatures that in many cases make it possible to obtain products with low CO content. For this, it is necessary to carry out the process using catalysts based on copper, nickel, or noble metals [17-23]. In particular, high catalytic activity of nickel-copper and platinum-rhodium alloys has been shown [24-28].

A support also plays an important role in the catalytical process [29-31]. It is generally accepted that a support provides water vapor adsorption [32]. The support composition, which is usually finely dispersed oxides of polyvalent elements such as zinc, aluminum, chromium, silicon, or mesoporous complex oxides [20,33], is also important. There is also information about the carbon supports use, in particular nanodiamonds. Their activity is primarily determined by the oxygen-containing groups $(\mathrm{OH}, \mathrm{CO}, \mathrm{COOH})$ located on the surface $[16,34]$. However, oxide carriers are more commonly used. It has been shown, for example, that the $\mathrm{Cu} / \mathrm{ZnO}$ catalysts selectivity with respect to carbon dioxide is provided by zirconia additives [35]. The use of zirconia itself as a catalyst support can also provide good results. Moreover, the catalyst activity can be improved by increasing in the support particles dispersion and by formation of its highly symmetric cubic modification as a result of oxide support doping with trivalent elements or cerium $\left(\mathrm{M}_{\mathrm{X}} \mathrm{Zr}_{1-\mathrm{X}} \mathrm{O}_{2-\delta}\right)$ [36]. It is known that oxygen ions in such materials are characterized by higher defect concentration and oxygen mobility [37]. An increase in the concentration of yttrium in $\mathrm{Y}_{\mathrm{X}} \mathrm{Zr}_{1-} \mathrm{XO}_{2-\delta}$ enables to increase the activity of the catalyst while maintaining the cubic structure of the support [38]. This made it possible to assume that the promoting activity of the action of the support is determined not so much by its structure as by the defect formation.

In recent years, considerable attention has been paid to supports based on titanium oxide, which is primarily associated with their use in photocatalytic transformations [39-42]. However, they started to be actively used in other areas, such as hydrogen production using electrolysis [43]. There are data about methanol steam reforming on titania-based catalysts $[33,44,45]$. Doping with trivalent and pentavalent elements can lead to defects formation in titania structure and affect their electrophysical properties, primarily oxygen ions mobility [46-50]. Since this had a promoting influence on MSR process on the zirconia based catalysts, the same can be expected for titanium oxide as well. At the same time, titanium oxide does not change structure upon doping.

When the support dopant is choosing, an attention should be paid first of all to the oxides of elements that have a valence of 3 or 5 and show catalytic activity in the similar catalytic processes themselves. This doping leads to the oxygen ions introduction into the interstices of the $\mathrm{ZrO}_{2}\left(\mathrm{O}_{\mathrm{i}}{ }^{\prime \prime}\right)$ lattice and to the formation of oxygen vacancies $\left(\mathrm{V}_{\mathrm{O}}{ }^{* *}\right)$ in it [51] in accordance with the equations of quasi-chemical reactions 3 and 4, respectively:

$$
\begin{gathered}
\mathrm{M}_{2} \mathrm{O}_{3} / \mathrm{TiO}_{2} \rightarrow 2 \mathrm{M}_{\mathrm{Ti}}{ }^{\prime}+3 \mathrm{O}_{\mathrm{O}}+\mathrm{V}_{\mathrm{O}}{ }^{* *} \\
\mathrm{M}_{2} \mathrm{O}_{5} / \mathrm{TiO}_{2} \rightarrow 2 \mathrm{M}_{\mathrm{Ti}^{*}}{ }^{*}+4 \mathrm{O}_{\mathrm{O}}+\mathrm{O}_{\mathrm{i}}{ }^{\prime \prime}
\end{gathered}
$$

where, according to the Kröger-Vink notation [52], the subscripts denote the localization of ions in the crystallographic positions of titanium and oxygen, and the superscripts " " " and "*" symbolize their negative and positive charge relative to a given position in the lattice.

Among trivalent element oxides, $\operatorname{In}_{2} \mathrm{O}_{3}$ initially attracts attention. In some cases, it is used as a catalyst, but its own activity is usually low [53-56]. In this regard, indium is often combined with more active metals of the platinum group [57-59]. It is believed that indium introduction leads to hydrogen and $\mathrm{CO}_{2}$ yields increases in the catalyst stability $[55,59]$. It should be noted that its use as a support often leads to the catalyst activity 
suppression, since reduced indium is supposed to be able to block the active sites on the metal surface $[59,60]$. At the same time, when indium oxide is used together with other oxides in the form of solid solutions, this negative effect can be suppressed [24,61-65].

It is worth paying attention to $\mathrm{Nb}_{2} \mathrm{O}_{5}$, which was used as a support in ethanol steam reforming $[66,67]$ and in some other processes, including CO oxidation $[68,69]$, ammonia oxidation [70] and photocatalytic hydrogen generation [71]. At the same time, carriers based on oxides of tetravalent elements doped with niobium in the MSR process are poorly studied.

In this regard, the aim of this work was a comparative study of the doping with niobium and indium effect on titania based supports for the methanol steam reforming catalysts, based on copper-nickel and platinum-rhodium alloys. It is worth noting in the comparison of titanium and zirconium oxides, that unlike $\mathrm{ZrO}_{2}$, titanium oxide cannot be obtained in the cubic modification. At the same time a number of authors have noted that an important point is the use of a support on the basis of a high-temperature $\mathrm{ZrO}_{2}$ modification [32]. To elucidate the possibility of a contribution of the support structure, it was of interest to compare copper-nickel catalysts with niobium-doped zirconium and titanium oxides as a support.

\section{Materials and Methods}

Titanium oxides doped with niobium and indium were synthesized according to the sol-gel method (Figure 1) similar to the described in [72]. At the first stage of In-dopped titania synthesis, a solution, containing isopropanol (Khimreagent, Karabulak, Russia, high purity grade) and titanium (IV) tetraisopropoxide $\mathrm{Ti}(\mathrm{OiPr})_{4}$ (Sigma-Aldrich, St. Louis, MO, USA, 97\%) in a volume ratio of 3:1, was prepared. A solution of $1 \mathrm{M}$ acetic acid (Khimmed, Moscow, Russia, chemically pure) in isopropanol was added to the obtained mixture dropwise under the continuous stirring on a magnetic stirrer; to complete the hydrolysis process and the sediment aging, the resulting emulsion was left at room temperature and continuously stirring for $24 \mathrm{~h}$. At the second stage of the synthesis, a solution of indium nitrate in isopropanol, preliminarily prepared by dissolving indium oxide (Sigma-Aldrich, St. Louis, MO, USA, 99.99\%) in concentrated nitric acid (Khimmed, Moscow, Russia, high purity grade), was added dropwise with constant stirring into the titanium hydroxide gel. After stirring for $12 \mathrm{~h}$ at room temperature, the precipitate was dried in an oven at $80^{\circ} \mathrm{C}$ and calcinated in a muffle furnace at the temperature of $500^{\circ} \mathrm{C}$ for $5 \mathrm{~h}$ and a heating rate of $5^{\circ}$ per minute. $\mathrm{Nb}$-doped titanium oxide was synthesized following the similar procedure. Niobium chloride solution (Sigma-Aldrich, St. Louis, MO, USA, 99.8\%) was taken as niobium precursor.

$\mathrm{Nb}$-doped zirconium oxide was obtained by the coprecipitation method (described in detail in [73]) of zirconium and niobium hydroxides with an ammonia solution from zirconium oxonitrate $\mathrm{ZrO}\left(\mathrm{NO}_{3}\right)_{2}$ (Sigma-Aldrich, 99\%) and niobium chloride (Acros, Moscow, Russia, 99.8\%) solutions with subsequent washing and freezing of the gel. The resulting product was annealed for an hour at $500{ }^{\circ} \mathrm{C}$ in a muffle furnace in air.

To obtain bimetallic Pt-Rh catalysts, the metals were deposited sequentially according to the procedure described in [34]. Polyvinylpyrrolidone (PVP) (Sigma-Aldrich) as the metal nanoparticles stabilizer and the calculated amount of oxide support was added to the metal precursor solution (rhodium (III) chloride (Sigma-Aldrich, 99.95\%) or hexachloroplatinic acid, previously obtained by dissolving the weighed sample of metal platinum in aqua regia) in water-ethylene glycol (Labtech, analytical grade) mixture ( $50 \%$ by volume) at stirring on the magnetic stirrer. The metals reduction was carried out by adding dropwise under the constant stirring a threefold excess of a freshly prepared $0.5 \mathrm{M} \mathrm{NaBH} 4$ (ABCR, Germany, 98\%) aqueous solution. After stirring for $40 \mathrm{~min}$, the suspension was filtered using a Buchner funnel, washed several times with deionized water and acetone. The resulting precipitate was dried at the temperature of $80^{\circ} \mathrm{C}$ for $3 \mathrm{~h}$. The molar ratio of metals was 1:1. 


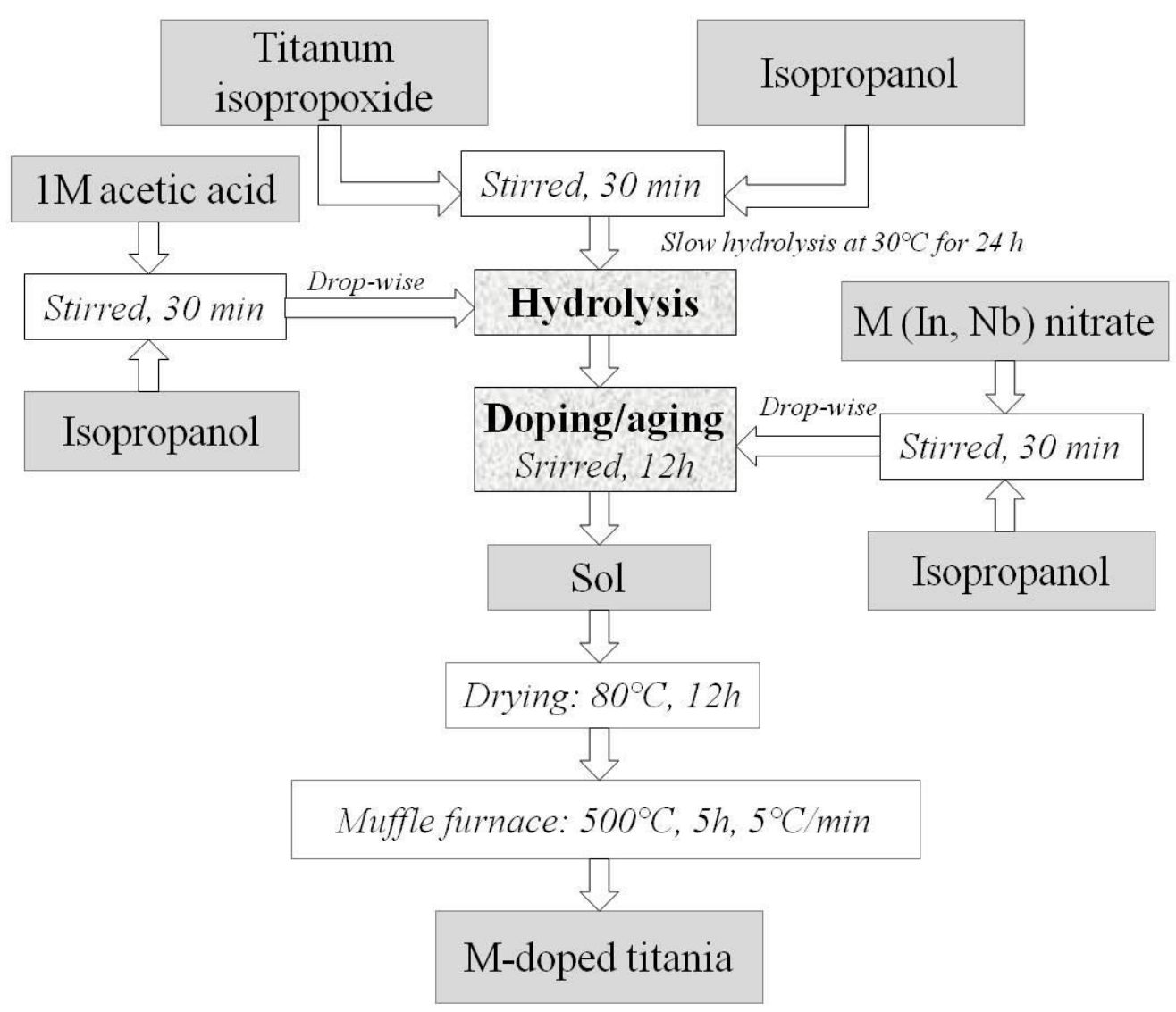

Figure 1. Scheme of doped titanium oxide synthesis.

To obtain $\mathrm{Cu}-\mathrm{Ni}$ catalysts, the similar procedure was used. The aqueous solutions of $\mathrm{Cu}\left(\mathrm{NO}_{3}\right)_{2} \bullet 3 \mathrm{H}_{2} \mathrm{O}$ (Khimmed, $>98 \%$ ) and $\mathrm{Ni}\left(\mathrm{NO}_{3}\right)_{2} \bullet 6 \mathrm{H}_{2} \mathrm{O}$ (Sigma-Aldrich, $\geq 98.5 \%$ ) were used as the metal precursors. The molar ratio of the metals was 4:1 and, as in the previous case, it was chosen on the base of the previous investigation results [24,34].

Before catalytic tests, the resulting catalysts were kept for $3 \mathrm{~h}$ in the mixture of $\mathrm{H}_{2}$ $(5 \%) / \mathrm{Ar}$ at $500{ }^{\circ} \mathrm{C}$ in a quartz reactor placed in a tubular furnace.

X-ray diffraction phase analysis (XRD) of the obtained samples was carried out using a X-ray diffractometer Rigaku D/Max-2200 (CuK $\alpha_{1}$-radiation). Rigaku Application Data Processing software package was used to process the spectra and qualitative analysis. Particles sizes (coherent scattering region) were estimated according to XRD peaks width using the Scherrer equation:

$$
d=\frac{k \cdot \lambda}{\left(B^{2}-b^{2}\right)^{1 / 2} \cdot \cos \theta}
$$

where $k=0.89$ is the Scherrer's constant; $\lambda=1.5406 \AA$ is the wavelength of the radiation used; $B$ is a peak half-width at half-height $(2 \theta) ; b$ is an instrumental broadening $(2 \theta) ; \theta$ is the diffraction angle. The width of the first, most intense peak of this phase was used for the assessment. For titanium oxide it was the line 101.

The specific surface area and pore size of the obtained catalysts were investigated by BET method on ASAP-2020N (Micromeritics Co, Norcross, GA, USA).

The microstructure of the samples was investigated using a transmission electron microscope Jeol JEM 2100 (Shared use research and development center MISIS, Moscow, Russia) with an accelerating voltage of $200 \mathrm{kV}$.

Methanol steam reforming was carried out under the atmospheric pressure in a conventional reactor in the temperature range of $200-400{ }^{\circ} \mathrm{C}$. A catalyst sample $(0.3 \mathrm{~g}$ load $)$ was mixed with granular quartz (fraction 1-3 mm) and placed in the middle of the reactor. 
The reactor heating was provided by an electric furnace. The temperature of the reactor was measured by a chromel-alumel thermocouple. Argon was used as a sweep gas (the flow of $20 \mathrm{~mL} / \mathrm{min}$ ). A liquid mixture of methanol and water with a stoichiometric molar ratio of 1:1 was supplied to the evaporator using an Instilar 1488 Dixion infusion pump. An increase in the water content leads to an increase in the methanol conversion and the yield of hydrogen, but in our opinion, such a ratio of reagents makes it possible to reveal the difference more clearly in the activity of the catalysts. Unreacted water and alcohol were condensed in a glass receiver cooled up to $+1^{\circ} \mathrm{C}$. The catalyst was regenerated after each experiment with the mixture of $5 \% \mathrm{H}_{2} / \mathrm{Ar}$ for $3 \mathrm{~h}\left(\mathrm{~T}=350{ }^{\circ} \mathrm{C}\right.$, mixture feed rate $20 \mathrm{~mL} / \mathrm{min}$ ).

The composition analysis of the non-condensed reaction products was carried out with the use of gas chromatograph LHM 8MD with a thermal conductivity detector, helium as a carrier gas and columns with a stationary phase Porapak $\mathrm{T}$ (for water, methanol and other oxygenates) and activated carbon (for $\mathrm{CO}$ and $\mathrm{CO}_{2}$ ). Concentrations of hydrogen and methane in the reaction products were determined by a chromatograph Chrom- 4 with a thermal conductivity detector and a zeolite column (CaA Zeosorb phase, Ar as a carrier gas). Chromatograms were processed with the use of the software package Ecochrom.

The process selectivity $(S, \%)$ and the conversion degree $(X, \%$ molar) were calculated using the Equations (6) and (7):

$$
\begin{gathered}
X_{\mathrm{CH}_{3} \mathrm{OH}}=\frac{n_{\mathrm{CH}_{3} \mathrm{OH}, \text { in }}-n_{\mathrm{CH}_{3} \mathrm{OH}, \text { out }}}{n_{\mathrm{CH}_{3} \mathrm{OH}, \text { in }}} \cdot 100 \% \\
S=\frac{n_{\mathrm{CO}_{2} \text { out }}}{n_{\mathrm{CO}_{2}, \text { out }}+n_{\mathrm{CO}, \text { out }}} \cdot 100 \%
\end{gathered}
$$

where $n_{\mathrm{CH}_{3} \mathrm{OH} \text {, in }}$ and $n_{\mathrm{CH}_{3} \mathrm{OH} \text {,out }}$ are the amounts of supplied and unreacted methanol, respectively, $n_{\mathrm{CO}_{2} \text {,out }}$ and $n_{\mathrm{CO} \text {,out }}$ are the amounts of carbon oxides in the reaction products. The product yields were estimated as the amount of the corresponding reaction product (in moles) formed per mole of methanol consumed. The GHSV value (gas hourly space velocity), calculated as the ratio of the entering volumetric flow rate $\left(765 \mathrm{~cm}^{3} / \mathrm{h}\right)$ to the volume of the catalytic layer, was $172 \mathrm{~h}^{-1}$. This parameter remained unchanged for all catalytic tests.

\section{Results and Discussion}

\subsection{The Catalysts and the Supports Properties}

Microprobe analysis data indicate that the catalyst composition corresponds to the stoichiometry of the starting components loading within the error. In the case of the $\mathrm{Cu}-\mathrm{Ni}$ alloys, the mole fraction of copper was of $75-82 \%$ and the total metal fraction in the catalyst was $20 \mathrm{wt} \%$. For the $\mathrm{Pt}-\mathrm{Rh}$ alloys, the molar fraction of platinum was of $45-56 \%$, and the total metal content was about $7 \mathrm{wt} \%$. X-ray patterns of the obtained supports indicate the formation of the corresponding materials based on zirconia and titania with a single-phase structure. In the case of zirconia, a cubic $\mathrm{Nb}_{0.1} \mathrm{Zr}_{0.9} \mathrm{O}_{2.05}$ sample was obtained, with the structure similar to the one described earlier when yttrium, cerium, and lanthanum were used as dopants [44]. The unit cell parameter of the obtained material was of $4.939 \pm 0.008 \AA$, and the particle size, estimated from the size of the coherent scattering region, was of $15 \pm 1 \mathrm{~nm}$. The assignment of doped zirconium oxide peaks is shown in the Figure 2 using $\mathrm{Zr}_{0.9} \mathrm{Nb}_{0.1} \mathrm{O}_{2.05}$ as an example. Due to the smaller particle size, the resolution of closely spaced lines in the region of $36-39^{\circ}$ is less pronounced for samples doped with indium.

In contrast, titanium dioxide-based materials crystallize in the anatase structure (tetragonal modification) (Figure 2). Moreover, the oxide support particles size turned out to be significantly smaller and amounted to $2.8 \pm 0.3$ and $5.2 \pm 0.5 \mathrm{~nm}$ for the samples doped with indium and niobium, respectively. Particle sizes of the platinum-rhodium alloy $\left(\mathrm{Pt}_{0.5} \mathrm{Rh}_{0.5}\right)$ deposited on the corresponding supports differed only within the measurement 
error and were of $5.4 \pm 0.5$ and $5.0 \pm 0.5 \mathrm{~nm}$ for the $\mathrm{In}$ - and $\mathrm{Nb}$-doped samples respectively. An alloy of copper with nickel $\left(\mathrm{Cu}_{0.8} \mathrm{Ni}_{0.2}\right)$ formed particles of significantly larger sizes (11 \pm 1 and $10 \pm 1 \mathrm{~nm}$, respectively). The reason for this difference in the metal particles sizes is the significantly lower melting temperature of copper and nickel, which leads to a higher value of the metals diffusion coefficient and the degree of particle aggregation. The higher size of metal particles in comparison with the oxide support is due to the same reason.

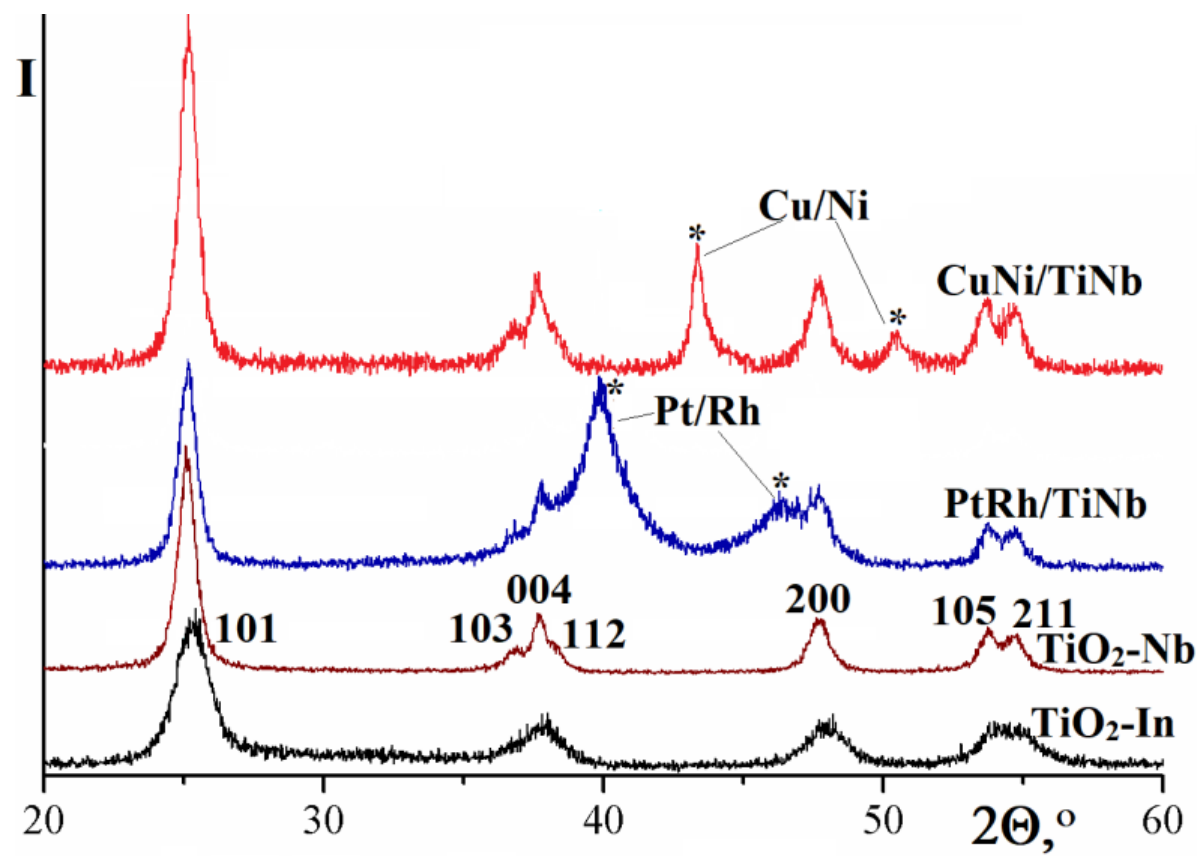

Figure 2. X-ray diffraction patterns of titanium oxide samples doped with indium, niobium and the catalysts based on them. The reflections corresponding to the bimetallic alloys are marked with asterisks $\left(^{*}\right)$.

Transmission electron microscopy data are in good agreement with the X-ray phase analysis results. The images clearly show a darker array of metal alloy particles and the oxide support lighter colored particles (Figure 3). Moreover, majority of the particles have the size close to that estimated from the CSR value, although there are particles of larger sizes at the same time (Figure 3c). Most likely, the majority of the large particles represent aggregates. On the basis of the presented illustrations, it is possible to estimate the value of interplanar distances. For example, Figure 3c shows the interplanar distances of $2.27 \AA$, corresponding to the 111 platinum-rhodium alloy reflex and $3.5 \AA$, answering to the 101 anatase reflex. The diffraction rings arrays, matching to the set of interplanar distances of tetragonal $\mathrm{TiO}_{2}$, cubic $\mathrm{ZrO}_{2}$, as well as $\mathrm{Cu}-\mathrm{Ni}$ and $\mathrm{Pt}-\mathrm{Rh}$ alloys can also be observed in the electron diffraction patterns of the corresponding samples.

The specific surface areas of the obtained catalysts (Table 1) were found to be quite close and varied from 45 to $68 \mathrm{~m}^{2} / \mathrm{g}$. Using the data on the studying materials density, it is also possible to estimate the average size of their particles; that for the catalysts based on zirconia was of 90-120 nm, and for the titania based materials around 55-80 nm. This indicates that all of the obtained supports are substantially prone to agglomeration, which increases after the metals deposition. 


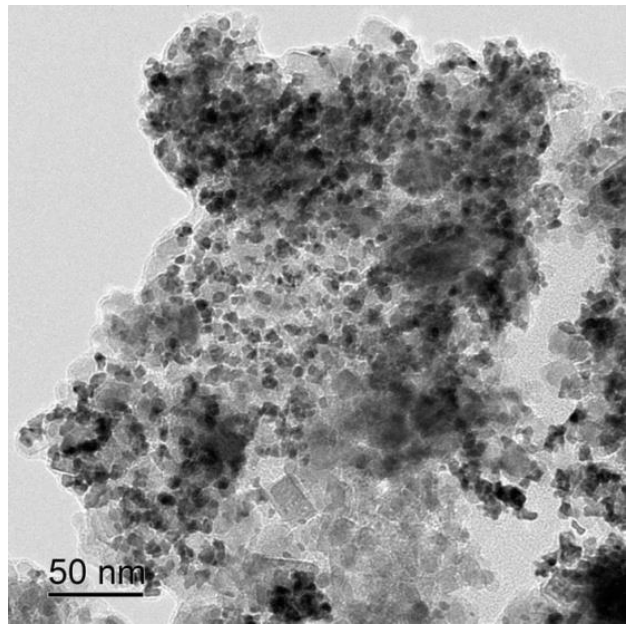

(a)

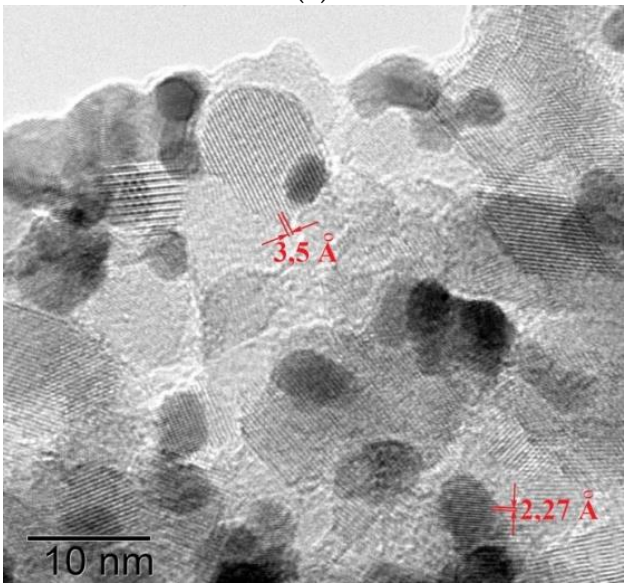

(c)

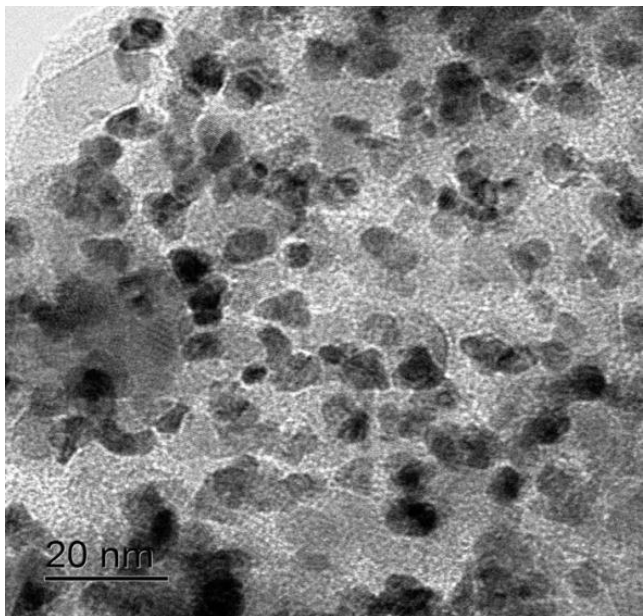

(b)

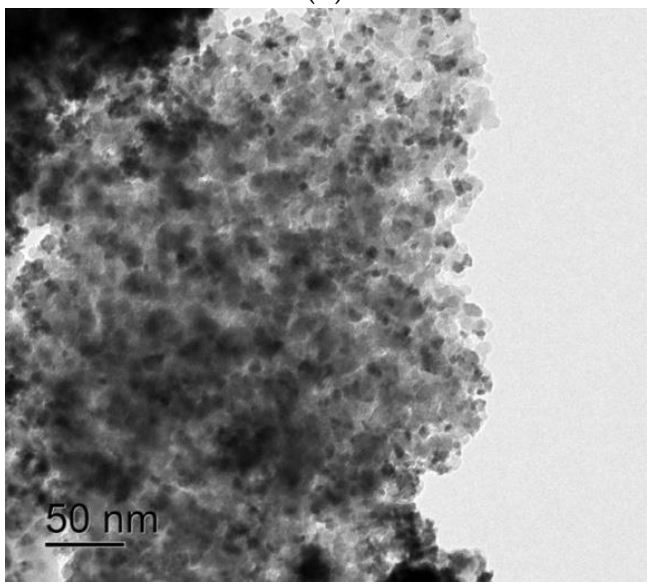

(d)

Figure 3. TEM images of $\mathrm{Pt}-\mathrm{Rh} / \mathrm{Ti}(\mathrm{Nb}) \mathrm{O}_{2}(\mathbf{a}-\mathbf{c})$ and $\mathrm{Cu}-\mathrm{Ni} / \mathrm{Zr}(\mathrm{Nb}) \mathrm{O}_{2}(\mathbf{d})$ samples.

Table 1. Composition, designation, particle size and surface area of the obtained samples.

\begin{tabular}{ccccc}
\hline Composition & Designation & $\begin{array}{c}\text { Surface Area, } \\
\mathbf{m}^{2} / \mathbf{g}\end{array}$ & \multicolumn{2}{c}{ Particle Sizes, $\mathbf{n m}$} \\
\cline { 5 - 5 } $\begin{array}{c}\mathrm{Cu}_{0.8^{-}} \\
\mathrm{Ni}_{0.2} / \mathrm{Zr}_{0.9} \mathrm{Nb}_{0.1} \mathrm{O}_{2.05}\end{array}$ & $\mathrm{CNZN}$ & $56 \pm 3$ & $15 \pm 1$ & $10 \pm 1$ \\
\hline $\begin{array}{c}\mathrm{Cu}_{0.8^{-}} \\
\mathrm{Ni}_{0.2} / \mathrm{Ti}_{0.9} \mathrm{In}_{0.1} \mathrm{O}_{1.95}\end{array}$ & $\mathrm{CNTI}$ & $54 \pm 3$ & $2.8 \pm 0.3$ & $10 \pm 1$ \\
\hline $\begin{array}{c}\mathrm{Cu}_{0.8^{-}} \\
\mathrm{Ni}_{0.2} / \mathrm{Ti}_{0.9} \mathrm{Nb}_{0.1} \mathrm{O}_{2.05}\end{array}$ & $\mathrm{CNTN}$ & $45 \pm 3$ & $5.2 \pm 0.5$ & $11 \pm 1$ \\
\hline $\mathrm{Pt}-\mathrm{Rh} / \mathrm{Ti}_{0.9} \mathrm{In}_{0.1} \mathrm{O}_{1.95}$ & PRTI & $68 \pm 4$ & $2.8 \pm 0.3$ & $5.4 \pm 0.5$ \\
\hline $\mathrm{Pt}-\mathrm{Rh} / \mathrm{Ti}_{0.9} \mathrm{Nb}_{0.1} \mathrm{O}_{2.05}$ & PRTN & $64 \pm 3$ & $5.2 \pm 0.5$ & $5.0 \pm 0.5$ \\
\hline
\end{tabular}

\subsection{Methanol Steam Reforming}

All investigated catalysts are active in the methanol steam reforming process. Moreover, the platinum-rhodium catalysts provide a higher hydrogen yield than the coppernickel one. The use of In-doped titania also leads to the hydrogen flow increase (Figure 4). Such regularity is observed for both types of used alloys. It can also be noted that an even higher hydrogen yield is achieved at the high temperatures on the $\mathrm{Cu}_{0.8}-\mathrm{Ni}_{0.2} / \mathrm{Ti}_{0.9} \mathrm{In}_{0.1} \mathrm{O}_{1.95}$ catalyst than in the case of $\mathrm{Pt}_{0.5}-\mathrm{Rh}_{0.5} / \mathrm{Ti}_{0.9} \mathrm{Nb}_{0.1} \mathrm{O}_{2.05}$. The difference between these two types of supports may lie in the intrinsic catalytic activity of indium oxide or in its pro- 
moting effect on the metal alloy catalytic activity. However, the attempt to increase the indium content, on the contrary, even led to a slight decrease in the catalytic activity of the materials obtained. Thus, the maximum hydrogen yield at $350{ }^{\circ} \mathrm{C}$ when using the $\mathrm{Pt}-\mathrm{Rh} / \mathrm{Ti}_{0.8} \mathrm{In}_{0.2} \mathrm{O}_{1.9}$ sample as a catalyst was only $1.96 \mathrm{~mol}$ of hydrogen per mol of alcohol, which is $30 \%$ less than for the catalyst $\mathrm{Cu}_{0.8}-\mathrm{Ni}_{0.2} / \mathrm{Ti}_{0.9} \mathrm{In}_{0.1} \mathrm{O}_{1.95}$.

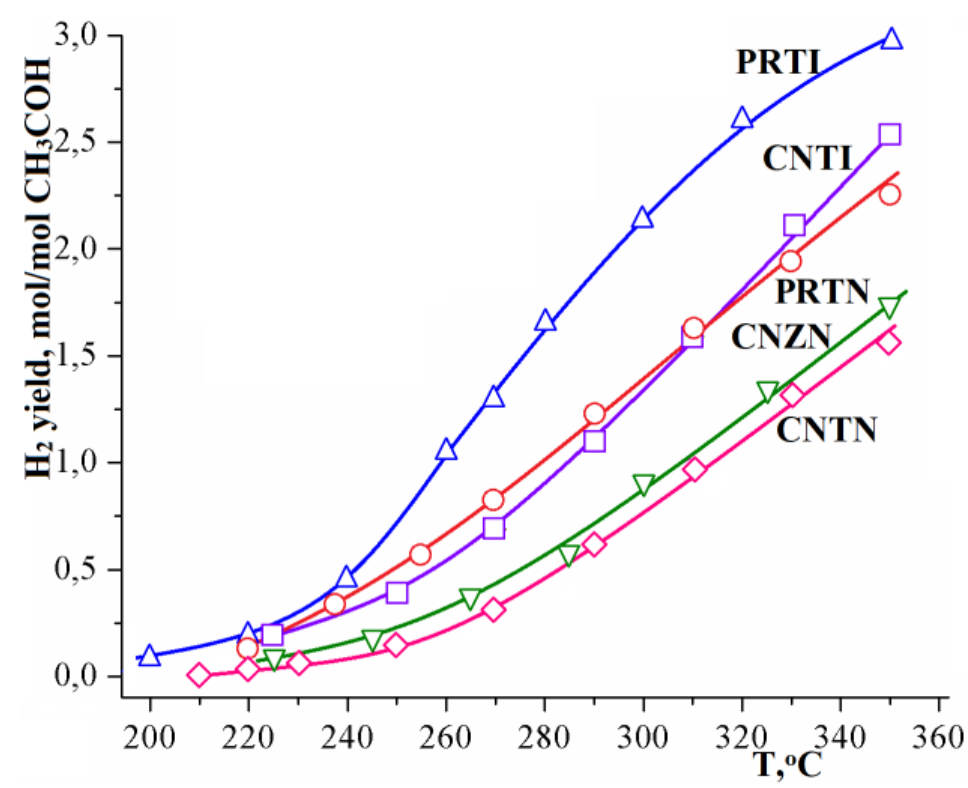

Figure 4. Temperature dependence of the hydrogen yield in the MSR using investigated catalysts.

Therefore, the most probable reason is the effect of a significant difference in the defect structure of the obtained carriers. Thus, doping titania with indium oxide takes place due to the quasi-chemical reaction (3). Accordingly, in the oxygen sublattice of the oxide structure vacancies are formed. As known, such vacancies are prone to sorption of oxygen atoms of water molecules [37], and oxygen ions can form hydrogen bonds with water protons. As noted above, the support role is largely reduced to water sorption, thus it is not surprising that the use of such catalysts can provide the successful steam reforming proceeding.

$\mathrm{TiO}_{2}$ doping with pentavalent niobium oxide, on the contrary, leads to the excess appearance of oxygen ions, which can be located at the interstitial sites of the lattice. However, since the close packing is formed by bulk oxygen ions in such systems, the interstitial sites have a significantly smaller size. Therefore, additional oxygen ions placement into them would lead to a significant increase in the system enthalpy. Another mechanism of charge compensation is realizing, that is the formation of cation vacancies, which also have a negative charge relative to the positions where $\mathrm{Ti}^{4+}$ ions should have been located. Such a system can adsorb water molecules mainly due to the hydrogen bonds with water protons formation. The weakening of the support adsorption activity also leads to a decrease in the catalyst activity as a whole.

It is worth noting that the catalytic activity of $\mathrm{Cu}_{0.8}-\mathrm{Ni}_{0.2} / \mathrm{Ti}_{0.9} \mathrm{Nb}_{0.1} \mathrm{O}_{2.05}$ and $\mathrm{Cu}_{0.8^{-}}$ $\mathrm{Ni}_{0.2} / \mathrm{Zr}_{0.9} \mathrm{Nb}_{0.1} \mathrm{O}_{2.05}$ samples turned out to be relatively close. It was noted in [43] that the highly defective cubic modification formation, characterized by high oxygen mobility, is favorable to provide a high catalytic activity of the systems containing zirconia-based supports. However, both catalysts based on titania have the same anatase structure and differ only in the defective center's nature. In this case, it is the material based on the support containing a high concentration of oxygen vacancies that exhibited a higher catalytic activity. On the other hand, the supports based on zirconia and titania with different structures and containing same type defects exhibit similar catalytic activity. Similarly, the activity of the catalysts $\mathrm{Cu}_{0.8}-\mathrm{Ni}_{0.2} / \mathrm{Zr}_{0.9} \mathrm{M}_{0.1} \mathrm{O}_{1.95}$ (where M-ions of trivalent La or Y) 
described in [36] are comparable to $\mathrm{Cu}_{0.8}-\mathrm{Ni}_{0.2} / \mathrm{Ti}_{0.9} \mathrm{In}_{0.1} \mathrm{O}_{1.95}$. This leads to the expectation that it is the presence of oxygen vacancies that improves the system catalytic activity.

The temperature dependence of the methanol conversion in the methanol-water system, shown in Figure 5, turns out to be similar to the dependence of the hydrogen yield (Figure 4). The main reason for this is the target reaction dominance (1), while the side reaction of methanol decomposition (2) proceeds in an insignificant degree (Figure 6).

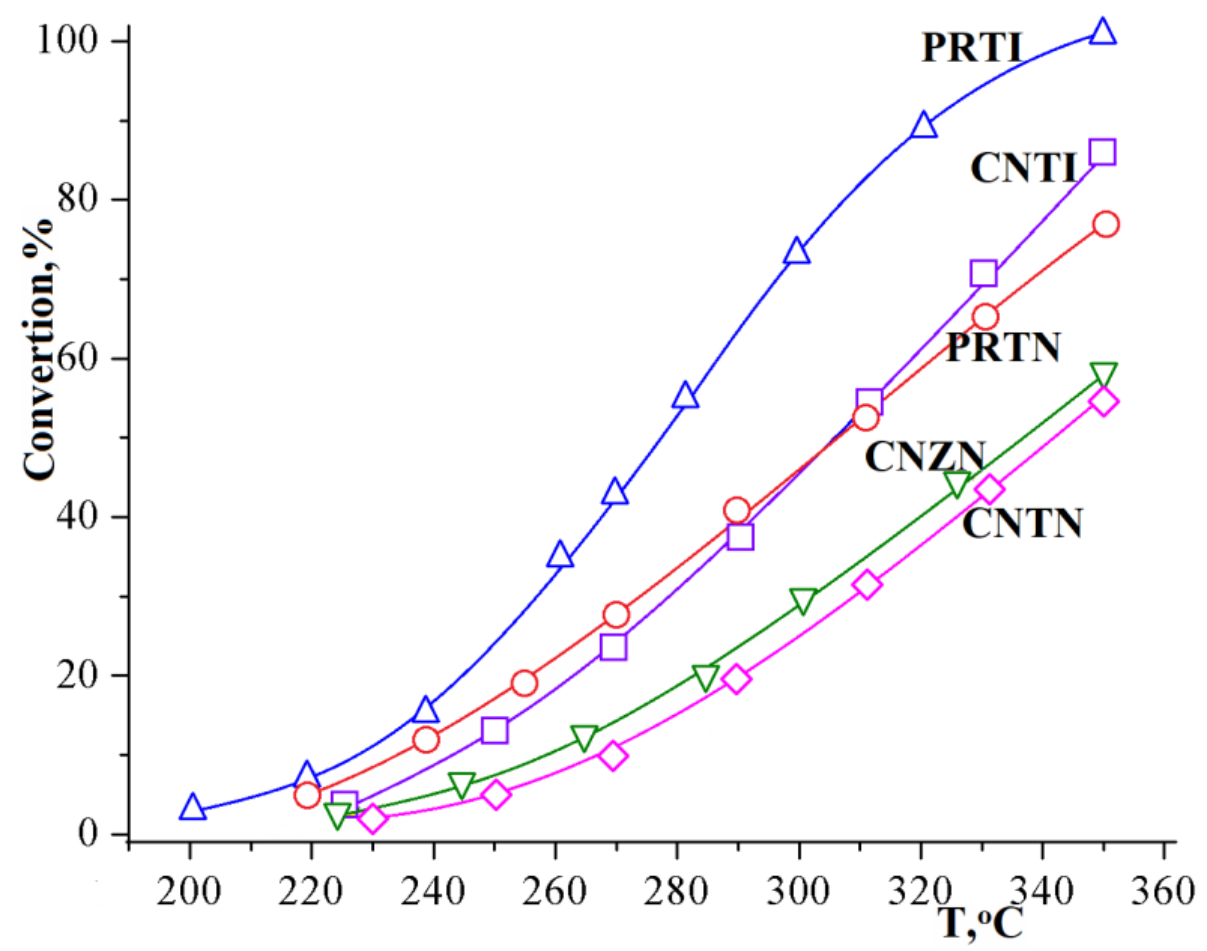

Figure 5. Temperature dependence of methanol conversion using various catalysts.

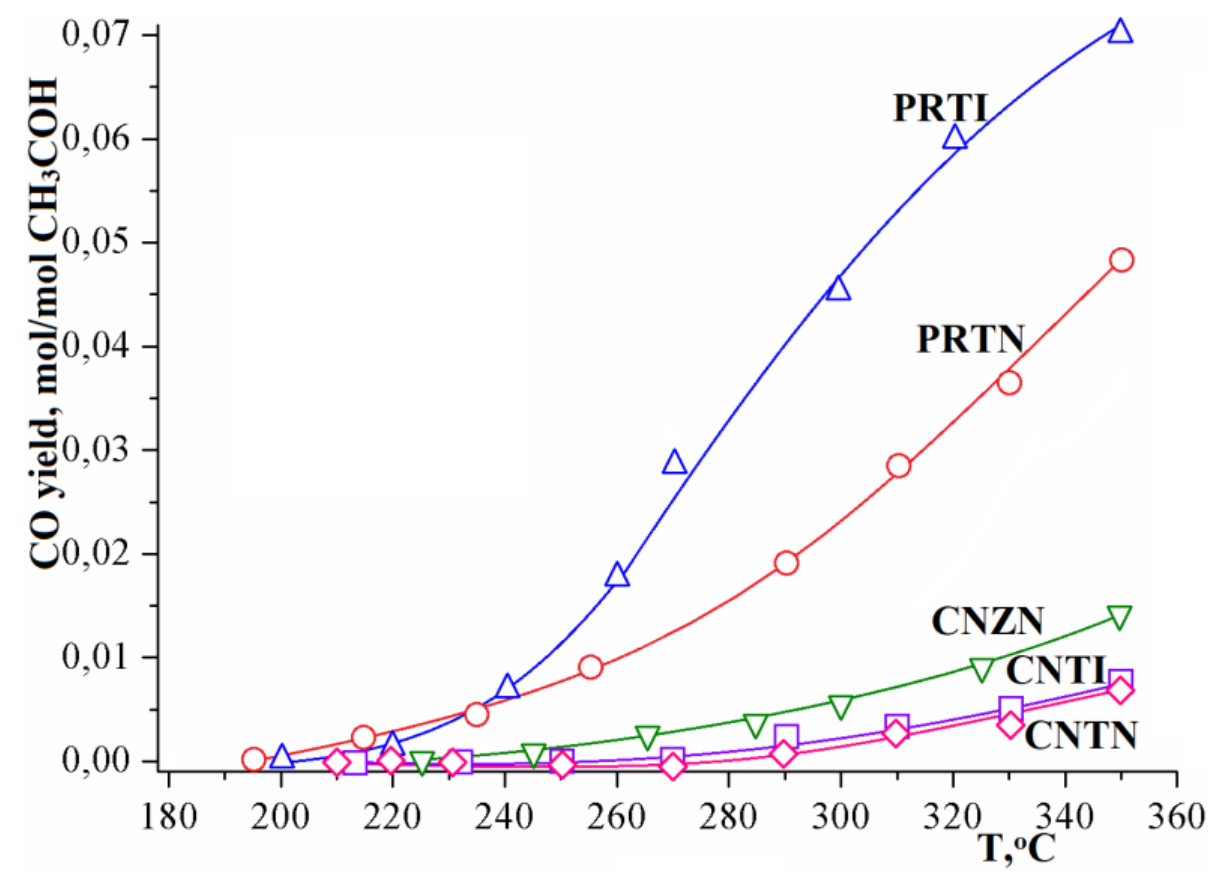

Figure 6. Temperature dependence of $\mathrm{CO}$ yield in the methanol-water (1:1) system using various catalysts. 
At the same time, carbon monoxide formation as a result of side reaction (2) proceeds much more actively on the platinum-rhodium catalyst. At the relatively low temperatures (up to $270{ }^{\circ} \mathrm{C}$ ), the concentration of $\mathrm{CO}$ in the methanol conversion products is so low that its impurities cannot be detected within the sensitivity of chromatographic analysis. And even at the high temperatures (up to $350{ }^{\circ} \mathrm{C}$ ), its content in the steam reforming products is extremely insignificant.

Thus, with a considerably higher hydrogen yield on the $\mathrm{Pt}-\mathrm{Rh} / \mathrm{Ti}_{0.9} \mathrm{M}_{0.1} \mathrm{O}_{1.95}$ catalyst, its selectivity in the steam reforming process turns out to be measurably lower than for the catalysts containing the $\mathrm{Cu}_{0.8}-\mathrm{Ni}_{0.2}$ alloy. The most likely reason for this is the higher methanol molecules binding strength on the surface of the $\mathrm{Pt}-\mathrm{Rh}$ particles. The result is an increased activity of this system both in the MSR process and in the decomposition of methanol by reaction (2).

In addition, it should be noted that the selectivity of MSR process turns out to be somewhat higher when using supports based on titanium oxide as compared to zirconium oxide (Figure 7). The selectivity of copper-nickel catalysts on the base of titania doped with indium and niobium seems to be quite comparable. At the same time, for the platinumrhodium catalyst, the selectivity is noticeably higher for the $\mathrm{Pt}-\mathrm{Rh} / \mathrm{Ti}_{0.9} \mathrm{Nb}_{0.1} \mathrm{O}_{2.05}$, system, while the catalytic activity, on the contrary, is maximum for the $\mathrm{Pt}-\mathrm{Rh} / \mathrm{Ti}_{0.9} \mathrm{In}_{0.1} \mathrm{O}_{1.95}$ sample.

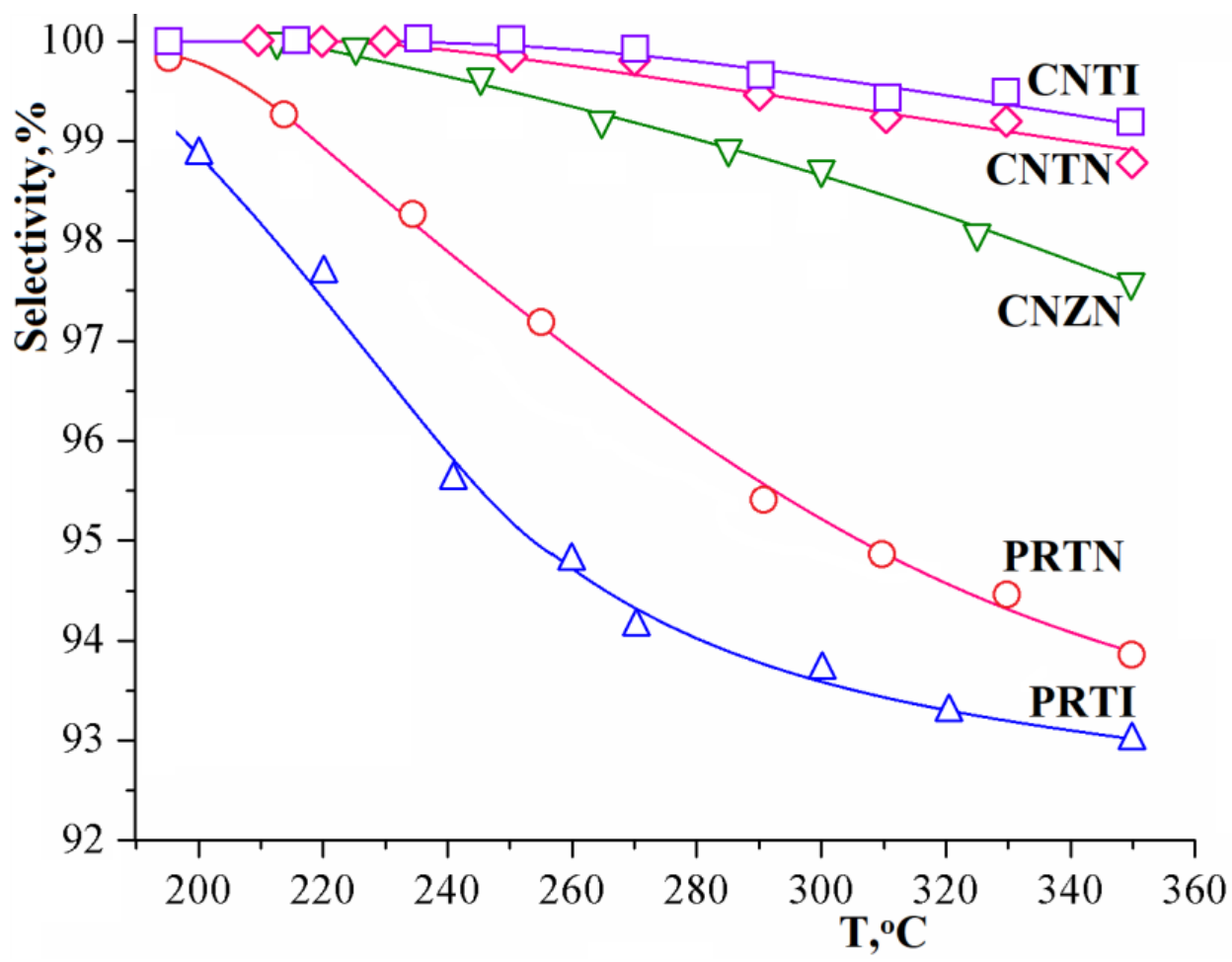

Figure 7. Temperature dependence of methanol conversion selectivity by reaction (1) in the methanolwater (1:1) system using various catalysts.

It is also worth noting that the catalysts did not carbonize during the MSR process and remained stable for at least $10 \mathrm{~h}$ of catalytic testing. During this time, the catalytic activity changed by no more than $7 \%$ and was completely restored after the above-described regeneration procedure. In addition, according to the X-ray data and electron microscopy, the phase composition of the samples does not change, and the particle size also remains stable during catalytic tests. The apparent reason is the higher calcination temperature of the samples during the synthesis.

Comparing the studied material properties, it can be noted that there is a certain correlation between the catalytic activity and the selectivity of various catalysts. First, it is determined by the metal properties or the alloy used as the catalyst base. The steam 
reforming process takes place at the interfaces between the metal particles and the oxide support, each of which performs its own specific function. In the case of copper-containing catalysts, the single-center adsorption of the methanol molecules through the oxygen atom is dominant, which leads to its relatively weak bonding, while the activation energy required for methanol destruction according to reaction (2) turns out to be quite high and this process can proceed only at sufficiently high temperatures [74]. At the same time, methanol molecule adsorption on platinum group metals turns out to be stronger and proceeds according to the two-center adsorption mechanism [29]. This facilitates both reactions for methanol steam reforming and the side reaction of methanol decomposition (2) with carbon monoxide formation, which can desorb without participation in the water gas shift reaction.

The support also plays an important role in the steam reforming process, as has already been mentioned. Its apparent role is included in water molecules adsorption. It takes place quite easily on the surface of highly dispersed samples, remaining in the form of $\mathrm{O}-\mathrm{H}$ groups even at high processing temperatures achieved in the course of catalytic experiments [73]. When a binary oxide $\left(\mathrm{MO}_{\mathrm{x}}\right)$ is used as a support, the bonding most likely occurs through the formation of hydrogen bond of a proton with oxide surface oxygen atoms and a coordination bond of water oxygen with the metal cations localized on the surface. More intense water adsorption and the catalytic process acceleration are facilitated by the formation of vacancies in oxygen positions upon titania doping with trivalent indium ions. At the same time, a sufficiently strong binding of water molecules makes it difficult to separate oxygen ions from the oxide surface. Therefore, this can simultaneously contribute to the occurrence of the undesirable methanol decomposition reaction with $\mathrm{CO}$ formation. On the other hand, titania doping with pentavalent atoms of niobium lowers the strength of oxygen binding, slows down the catalytic process and to a greater extent suppresses the side reaction (2). The influence of the dopants catalytic activity is small due to their low content and low intrinsic catalytic activity [36,53].

\section{Conclusions}

In this work, a comparative study of methanol steam reforming process on the platinum-rhodium and copper-nickel catalysts based on the indium or niobium doped titania supports has been carried out. The conclusions obtained show a significant effect of both the metal alloy and the oxide support nature on the activity and selectivity of the methanol steam reforming process. Moreover, in the considered systems, an increase in the catalyst activity leads to a decrease in its selectivity. Thus, the use of the platinum-rhodium alloy makes it possible to increase hydrogen yield in the MSR process. A transition to the copper-nickel catalysts causes a slight decrease in the methanol conversion degree. At the same time, this significantly reduces the carbon monoxide yield, which is a catalytic poison for the fuel cell catalysts. Heterovalent indium doping of titania used as a support also leads to the catalytic activity increase. It has been suggested that this is due to the defects in the oxygen $\mathrm{TiO}_{2}$ sublattice formation. On the contrary, our findings have shown that the use of niobium oxide as a dopant decreases the catalyst activity in the MSR process but leads to the selectivity increase.

Author Contributions: Conceptualization, A.L.-P.; Data curation, A.Y.; Formal analysis, A.L.-P. and N.T.; Investigation, A.L.-P.; Resources, N.T.; Software, N.T.; Supervision, A.Y.; Writing-original draft, A.L.-P.; Writing-review \& editing, A.Y. All authors have read and agreed to the published version of the manuscript.

Funding: The work was carried out within the framework of the state assignment of the Ministry of Education and Science of the Russian Federation at the TIHS RAS.

Institutional Review Board Statement: Not applicable.

Informed Consent Statement: Not applicable.

Conflicts of Interest: The authors declare no conflict of interest. 


\section{References}

1. Dehghani-Sanij, A.R.; Tharumalingam, E.; Dusseault, M.B.; Fraser, R. Study of energy storage systems and environmental challenges of batteries. Renew. Sustain. Energy Rev. 2019, 104, 192-208. [CrossRef]

2. Filippov, S.P.; Yaroslavtsev, A.B. Hydrogen energy: Development prospects and materials. Rus. Chem. Rev. 2021, 90, 627-643. [CrossRef]

3. Sanij, D.; Balakrishnan, P.; Leung, P.; Shah, A.; Su, H.; Xu, Q. Advanced Pd-based nanomaterials for electro-catalytic oxygen reduction in fuel cells: A review. Int. J. Hydrogen Energy 2021, 46, 14596-14627. [CrossRef]

4. Tsodikov, M.V.; Kurdymov, S.S.; Konstantinov, G.I.; Murzin, V.Y.; Bukhtenko, O.V.; Maksimov, Y.V. Core-shell bifunctional catalyst for stream methane reforming resistant to $\mathrm{H}_{2} \mathrm{~S}$ : Activity and structure evolution. Int. J. Hydrogen Energy 2015, 40, 2963-2970. [CrossRef]

5. Sengodan, S.; Lan, R.; Humphreys, J.; Du, D.; Xu, W.; Wang, H.; Tao, S. Advances in reforming and partial oxidation of hydrocarbons for hydrogen production and fuel cell applications. Renew. Sustain. Energy Rev. 2018, 82, 761-780. [CrossRef]

6. Jeppesen, C.; Polverino, P.; Andreasen, S.J.; Araya, S.S.; Simon, S.L.; Sahlin, L.; Pianese, C.; Knudsen, S. Impedance characterization of high temperature proton exchange membrane fuel cell stack under the influence of carbon monoxide and methanol vapor. Int. J. Hydrogen Energy 2017, 42, 21901-21912. [CrossRef]

7. Sutharssan, T.; Montalvao, D.; Chen, Y.K.; Wang, W.C.; Pisac, C.; Elemara, H. A review on prognostics and health monitoring of proton exchange membrane fuel cell. Renew. Sustain. Energy Rev. 2017, 75, 440-450. [CrossRef]

8. Pinaeva, L.G.; Noskov, A.S.; Parmon, V.N. Prospects for the direct catalytic conversion of methane into useful chemical products. Catal. Chem. Petrochem. Ind. 2017, 9, 283-298. [CrossRef]

9. Wang, D.; Zhang, J.; Sun, J.B.; Gao, W.M.; Cui, Y.B. Effect of metal additives on the catalytic performance of $\mathrm{Ni} / \mathrm{Al}_{2} \mathrm{O}_{3}$ catalyst in thermocatalytic decomposition of methane. Int. J. Hydrogen Energy 2019, 44, 7205-7215. [CrossRef]

10. Ouyang, M.Z.; Boldrin, P.; Maher, R.C.; Chen, X.L.; Liu, X.H.; Cohen, L.F.; Brandon, N.P. A mechanistic study of the interactions between methane and nickel supported on doped ceria. Appl. Catal. B Environ. 2019, 248, 332-340. [CrossRef]

11. Sánchez-Bastardo, N.; Schlögl, R.; Ruland, H. Methane Pyrolysis for $\mathrm{CO}_{2}$-Free $\mathrm{H}_{2}$ Production: A Green Process to Overcome Renewable Energies Unsteadiness. Chem. Ing. Tech. 2020, 92, 1596-1609. [CrossRef]

12. Kutteri, D.A.; Wang, I.W.; Samanta, A.; Li, L.L.; Hu, J.L. Methane decomposition to tip and base grown carbon nanotubes and $\mathrm{COx}$-free $\mathrm{H}_{2}$ over mono- and bimetallic 3d transition metal catalysts. Catal. Sci. Technol. 2018, 8, 858-869. [CrossRef]

13. Nishii, H.; Miyamoto, D.; Umeda, Y.; Hamaguchi, H.; Suzuki, M.; Tanimoto, T.; Harigai, T.; Takikawa, H.; Suda, Y. Catalytic activity of several carbons with different structures for methane decomposition and by-produced carbons. Appl. Surf. Sci. 2019, 473, 291-297. [CrossRef]

14. Hong, Z.; Xiong, C.; Zhao, G.; Zhu, Z. Side-chain alkylation of toluene with methanol to produce styrene: An overview. Catal. Sci. Technol. 2019, 9, 6828-6840. [CrossRef]

15. Brunetti, A.; Sun, Y.; Caravella, A.; Drioli, E.; Barbieri, G. Process intensification for greenhouse gas separation from biogas: More efficient process schemes based on membrane-integrated systems. Int. J. Greenh. Gas Control 2015, 35, 18-29. [CrossRef]

16. Mironova, E.Y.; Lytkina, A.A.; Ermilova, M.M.; Efimov, M.N.; Zemtsov, L.M.; Orekhova, N.V.; Karpacheva, G.P.; Bondarenko, G.N.; Yaroslavtsev, A.B.; Muraviev, D.N. Ethanol and methanol steam reforming on transition metal catalysts supported on detonation synthesis nanodiamonds for hydrogen production. Int. J. Hydrogen Energy 2015, 40, 3557-3565. [CrossRef]

17. Kovalskii, A.M.; Matveev, A.T.; Popov, Z.I.; Volkov, I.N.; Sukhanova, E.V.; Konopatsky, A.S.; Leybo, D.V.; Shchetinin, I.V.; Shtansky, D.V.; Lytkina, A.A.; et al. (Ni,Cu)/hexagonal BN nanohybrids-New efficient catalysts for methanol steam reforming and carbon monoxide oxidation. Chem. Eng. J. 2020, 395, 125109. [CrossRef]

18. Ploner, K.; Nezhad, P.D.K.; Nezhad, S.; Watschinger, M.; Schlicker, L.; Bekheet, M.F.; Gurlo, A.; Gili, A.; Doran, A.; Schwarz, S.; et al. Steering the methanol steam reforming performance of $\mathrm{Cu} / \mathrm{ZrO}_{2}$ catalysts by modification of the $\mathrm{Cu}-\mathrm{ZrO} 2$ interface dimensions resulting from $\mathrm{Cu}$ loading variation. Appl. Catal. A Gen. 2021, 623, 118279. [CrossRef]

19. Santamaria, L.; Lopez, G.; Arregi, A.; Artetxe, M.; Amutio, M.; Bilbao, J.; Olazar, M. Catalytic steam reforming of biomass fast pyrolysis volatiles over Ni-Co bimetallic catalysts. J. Ind. Eng. Chem. 2020, 91, 167-181. [CrossRef]

20. Abrokwah, R.Y.; Deshmane, V.G.; Kuila, D. Comparative performance of M-MCM-41 (M: Cu, Co, Ni, Pd, Zn and Sn) catalysts for steam reforming of methanol. J. Mol. Catal. A Chem. 2016, 425, 10-20. [CrossRef]

21. He, J.; Yang, Z.; Zhang, L.; Li, Y.; Pan, L. Cu supported on ZnAl-LDHs precursor prepared by in-situ synthesis method on g- $\mathrm{Al}_{2} \mathrm{O}_{3}$ as catalytic material with high catalytic activity for methanol steam reforming. Int. J. Hydrogen Energy 2017, 42, 9930-9937. [CrossRef]

22. Qing, S.-J.; Hou, X.-N.; Liu, Y.-J.; Wang, L.; Li, L.-D.; Gao, Z.-X. Catalytic performance of Cu-Ni-Al spinel for methanol steam reforming to hydrogen. J. Fuel Chem. Technol. 2018, 46, 1210-1217. [CrossRef]

23. Scotti, N.; Bossola, F.; Zaccheria, F.; Ravasio, N. Copper-zirconia catalysts: Powerful multifunctional catalytic tools to approach sustainable processes. Catalysts 2020, 10, 168. [CrossRef]

24. Lytkina, A.A.; Zhilyaeva, N.A.; Ermilova, M.M.; Yaroslavtsev, A.B. Influence of the support structure and composition of $\mathrm{Ni}-\mathrm{Cu}$-based catalysts on hydrogen production by methanol steam reforming. Int. J. Hydrogen Energy 2015, 40, 9677-9684. [CrossRef] 
25. Lytkina, A.A.; Orekhova, N.V.; Ermilova, M.M.; Petriev, I.S.; Baryshev, M.G.; Yaroslavtsev, A.B. Ru-Rh based catalysts for hydrogen production via methanol steam reforming in conventional and membrane reactors. Int. J. Hydrogen Energy 2019, 44, 13310-13322. [CrossRef]

26. Huang, C.-Y.; Sun, Y.-M.; Chou, C.-Y.; Su, C.-C. Performance of catalysts CuO-ZnO- $\mathrm{Al}_{2} \mathrm{O}_{3}, \mathrm{CuO}-\mathrm{ZnO}-\mathrm{Al}_{2} \mathrm{O}_{3}-\mathrm{Pt}-\mathrm{Rh}$, and Pt-Rh in a small reformer for hydrogen generation. J. Power Sources 2007, 166, 450-457. [CrossRef]

27. Li, J.; Mei, X.; Zhang, L.; Yu, Z.; Liu, Q.; Wei, T.; Wu, W.; Dong, D.; Xu, L.; Hu, X. A comparative study of catalytic behaviors of $\mathrm{Mn}, \mathrm{Fe}, \mathrm{Co}, \mathrm{Ni}, \mathrm{Cu}$ and $\mathrm{Zn}$-based catalysts in steam reforming of methanol, acetic acid and acetone. Int. J. Hydrogen Energy 2020, 45, 3815-3832. [CrossRef]

28. Mosinska, M.; Stępińska, N.; Maniukiewicz, W.; Rogowski, J.; Mierczynska-Vasilev, A.; Vasilev, K.; Szynkowska, M.I.; Mierczyński, P. Hydrogen production on Cu-Ni catalysts via the oxy-steam reforming of methanol. Catalysts 2020, 10, 273. [CrossRef]

29. Sá, S.; Silva, H.; Brandão, L.; Sousa, J.M.; Mendes, A. Catalysts for methanol steam reforming-A review. Appl. Catal. B Environ. 2010, 99, 43-57. [CrossRef]

30. Chen, L.; Qi, Z.; Peng, X.; Chen, J.-L.; Pao, C.-W.; Zhang, X.; Dun, C.; Young, M.; Prendergast, D.; Urban, J.J.; et al. Insights into the Mechanism of Methanol Steam Reforming Tandem Reaction over $\mathrm{CeO}_{2}$ Supported Single-Site Catalysts. J. Am. Chem. Soc. 2021, 43, 12074-12081. [CrossRef]

31. Ranjekar, A.M.; Yadav, G.D. Steam reforming of methanol for hydrogen production: A critical analysis of catalysis, processes, and scope. Ind. Eng. Chem. Res. 2021, 60, 89-113. [CrossRef]

32. Lytkina, A.A.; Orekhova, N.V.; Yaroslavtsev, A.B. Catalysts for the Steam Reforming and Electrochemical Oxidation of Methanol. Inorg. Mater. 2018, 54, 1315-1329. [CrossRef]

33. Deshmane, V.G.; Owen, S.L.; Abrokwah, R.Y.; Kuila, D. Mesoporous nanocrystalline $\mathrm{TiO}_{2}$ supported metal (Cu, Co, Ni, Pd, Zn, and Sn) catalysts: Effect of metal-support interactions on steam reforming of methanol. J. Mol. Catal. A Chem. 2015, 408, 202-213. [CrossRef]

34. Lytkina, A.A.; Orekhova, N.V.; Ermilova, M.M.; Belenov, S.V.; Guterman, V.E.; Efimov, M.N.; Yaroslavtsev, A.B. Bimetallic carbon nanocatalysts for methanol steam reforming in conventional and membrane reactors. Catal. Today 2016, 269, 60-67. [CrossRef]

35. Agrell, J.; Birgersson, H.; Boutonnet, M.; Melián-Cabrera, I.; Navarro, R.M.; Fierro, J.L.G. Production of hydrogen from methanol over $\mathrm{Cu} / \mathrm{ZnO}$ catalysts promoted by $\mathrm{ZrO}_{2}$ and $\mathrm{Al}_{2} \mathrm{O}_{3}$. J. Catal. 2003, 219, 389-403. [CrossRef]

36. Lytkina, A.A.; Orekhova, N.V.; Ermilova, M.M.; Yaroslavtsev, A.B. The influence of the support composition and structure $\left(\mathrm{MxZr}_{1-\mathrm{x}} \mathrm{O}_{2-\mathrm{d}}\right)$ of bimetallic catalysts on the activity in methanol steam reforming. Int. J. Hydrogen Energy 2018, 43, 198-207. [CrossRef]

37. Kasyanova, A.V.; Rudenko, A.O.; Lyagaeva, J.G.; Medvedev, D.A. Lanthanum-Containing Proton-Conducting Electrolytes with Perovskite Structures. Membr. Membr. Technol. 2021, 3, 73. [CrossRef]

38. Lytkina, A.A.; Orekhova, N.V.; Ermilova, M.M.; Petriev, I.S.; Baryshev, M.G.; Yaroslavtsev, A.B. Methanol Steam Reforming over $\mathrm{ZrO}_{2}$-Supported Catalysts in Conventional and Membrane Reactors. Petroleum Chem. 2017, 57, 1219-1227. [CrossRef]

39. Dholam, R.; Patel, N.; Miotello, A. Efficient $\mathrm{H}_{2}$ production by water-splitting using indiumetin-oxide/V-doped TiO ${ }_{2}$ multilayer thin film photocatalyst. Int. J. Hydrogen Energy 2011, 36, 6519-6528. [CrossRef]

40. Chiarello, G.L.; Ferri, D.; Selli, E. In situ attenuated total reflection infrared spectroscopy study of the photocatalytic steam reforming of methanol on Pt/ $\mathrm{TiO}_{2}$. Appl. Surf. Sci. 2018, 450, 146-154. [CrossRef]

41. Baamran, K.S.; Tahir, M. Ni-embedded $\mathrm{TiO}_{2}-\mathrm{ZnTiO}_{3}$ reducible perovskite composite with synergistic effect of metal/support towards enhanced $\mathrm{H}_{2}$ production via phenol steam reforming. Energy Convers. Manag. 2019, 200, 112064. [CrossRef]

42. Baamran, K.S.; Tahir, M.; Mohamed, M.; Hussain Khoja, A. Effect of support size for stimulating hydrogen production in phenol steam reforming using Ni-embedded $\mathrm{TiO}_{2}$ nanocatalyst. J. Environ. Chem. Eng. 2020, 8, 103604. [CrossRef]

43. Alcaide, F.; Genova, R.V.; Alvarez, G.; Grande, H.-J.; Miguel, O.; Cabot, P.L. Platinum-catalyzed Nb doped TiO 2 and Nb-doped $\mathrm{TiO}_{2}$ nanotubes for hydrogen generation in proton exchange membrane water electrolyzers. Int. J. Hydrogen Energy 2020, 45, 20605-20619. [CrossRef]

44. Tahay, P.; Khani, Y.; Jabari, M.; Bahadoran, F.; Safari, N. Highly porous monolith/ $\mathrm{TiO}_{2}$ supported Cu, Cu-Ni, $\mathrm{Ru}$, and Pt catalysts in methanol steam reforming process for $\mathrm{H}_{2}$ generation. Appl. Catal. A Gen. 2018, 554, 44-53. [CrossRef]

45. Khani, Y.; Tahay, P.; Bahadoran, F.; Safaria, N.; Soltanali, S.; Alavi, A. Synergic effect of heat and light on the catalytic reforming of methanol over $\mathrm{Cu} / \mathrm{x}-\mathrm{TiO}_{2}(\mathrm{x}=\mathrm{La}, \mathrm{Zn}, \mathrm{Sm}, \mathrm{Ce})$ nanocatalysts. Appl. Catal. A Gen. 2020, 594, 117456. [CrossRef]

46. Al Saqri, N.A.; Mondal, A.; Felix, J.F.; Gobato, Y.G.; Gordo, V.O.; Albalawi, H.; Jameel, D.; Alghamdi, H.; Al Mashary, F.; Taylor, D.; et al. Investigation of defects in indium doped $\mathrm{TiO}_{2}$ thin films using electrical and optical techniques. J. Alloys Compd. 2017, 698, 883-891. [CrossRef]

47. Djeghlouf, A.; Hamri, D.; Teffahi, A.; Saidane, A.; Al Mashary, F.S.; Al Huwayz, M.M.; Henini, M.; Orak, I.; Albadri, A.M.; Alyamani, A.Y. Effect of indium doping on the electrical and structural properties of $\mathrm{TiO}_{2}$ thin films used in MOS devices. J. Alloys Compd. 2019, 775, 202-213. [CrossRef]

48. Shahraki, M.M.; Mahmoudi, P.; Karimi, A. Air quenching as a reliable technique to obtain colossal dielectric constant with low loss in (In, Nb)-co doped $\mathrm{TiO}_{2}$. Mater. Lett. 2020, 267, 127513. [CrossRef]

49. Ribeiro, J.M.; Correia, F.C.; Kuzmin, A.; Jonane, I.; Kong, M.; Goñi, A.R.; Reparaz, J.S.; Kalinko, A.; Welter, E.; Tavares, C.J. Influence of $\mathrm{Nb}$-doping on the local structure and thermoelectric properties of transparent $\mathrm{TiO}_{2}: \mathrm{Nb}$ thin films. J. Alloys Compd. 2020, 838, 155561. [CrossRef] 
50. Al Mashary, F.S.; Felix, J.F.; Ferreira, S.O.; de Souza, D.; Gobato, Y.G.; Chauhan, J.; Alexeeva, N.; Henini, M.; Albadri, A.M.; Alyamani, A.Y. Investigation of the structural, optical and electrical properties of indium-doped $\mathrm{TiO}_{2}$ thin films grown by Pulsed Laser Deposition technique on low and high index GaAs planes. Mater. Sci. Eng. B 2020, 259, 114578. [CrossRef]

51. Yaroslavtsev, A.B. Solid electrolytes: Main prospects of research and development. Rus. Chem. Rev. 2016, 85, 1255-1276. [CrossRef]

52. Kröger, F.A.; Vink, H.J. Relations between the Concentrations of Imperfections in Crystalline Solids. Solid State Phys. 1956, 3, 307-435. [CrossRef]

53. Gervasini, A.; Perdigon-Melon, J.A.; Guimon, C.; Auroux, A. An in-depth study of supported $\operatorname{In}_{2} \mathrm{O}_{3}$ catalysts for the selective catalytic reduction of NOx: The influence of the oxide support. J. Phys. Chem. B 2006, 110, 240-249. [CrossRef] [PubMed]

54. Lorenz, H.; Jochum, W.; Klötzer, B.; Stöger-Pollach, M.; Schwarz, S.; Pfaller, K.; Penner, S. Novel methanol steam reforming activity and selectivity of pure $\mathrm{In}_{2} \mathrm{O}_{3}$. Appl. Catal. A Gen. 2008, 347, 34-42. [CrossRef]

55. Wang, J.; Wang, H.; Hu, P. Theoretical insight into methanol steam reforming on indium oxide with different coordination environments. Sci. China Chem. 2018, 61, 336-343. [CrossRef]

56. Ploner, K.; Schlicker, L.; Gili, A.; Gurlo, A.; Doran, A.; Zhang, L.; Armbrüster, M.; Obendorf, D.; Bernardi, J.; Klötzer, B.; et al. Reactive metal-support interaction in the $\mathrm{Cu}-\mathrm{In}_{2} \mathrm{O}_{3}$ system: Intermetallic compound formation and its consequences for $\mathrm{CO}_{2}$-selective methanol steam reforming. Sci. Technol. Adv. Mater. 2019, 20, 356-366. [CrossRef]

57. Men, Y.; Kolb, G.; Zapf, R.; O'Connell, M.; Ziogas, A. Methanol steam reforming over bimetallic Pd-In/ $\mathrm{Al}_{2} \mathrm{O}_{3}$ catalysts in a microstructured reactor. Appl. Catal. A Gen. 2010, 380, 15-20. [CrossRef]

58. Barbosa, R.L.; Papaefthimiou, V.; Law, Y.T.; Teschner, D.; Hävecker, M.; Knop-Gericke, A.; Zapf, R.; Kolb, G.; Schlögl, R.; Zafeiratos, S. Methanol steam reforming over indium-promoted $\mathrm{Pt} / \mathrm{Al}_{2} \mathrm{O}_{3}$ catalyst: Nature of the active surface. J. Phys. Chem. C 2013, 117, 6143-6150. [CrossRef]

59. Neumann, M.; Teschner, D.; Knop-Gericke, A.; Reschetilowski, W.; Armbrüster, M. Controlled synthesis and catalytic properties of supported In-Pd intermetallic compounds. J. Catal. 2016, 340, 49-59. [CrossRef]

60. Matsumura, Y.; Ishibe, H. Durable copper-zinc catalysts modified with indium oxide in high temperature steam reforming of methanol for hydrogen production. J. Power Sources 2012, 209, 72-80. [CrossRef]

61. Wichert, M.; Zapf, R.; Ziogas, A.; Kolb, G.; Klemm, E. Kinetic investigations of the steam reforming of methanol over a $\mathrm{Pt} / \mathrm{In}_{2} \mathrm{O}_{3} / \mathrm{Al}_{2} \mathrm{O}_{3}$ catalyst in microchannels. Chem. Eng. Sci. 2016, 155, 201-209. [CrossRef]

62. Liu, D.; Men, Y.; Wang, J.; Kolb, G.; Liu, X.; Wang, Y.; Sun, Q. Highly active and durable $\mathrm{Pt} / \mathrm{In}_{2} \mathrm{O}_{3} / \mathrm{Al}_{2} \mathrm{O}_{3}$ catalysts in methanol steam reforming. Int. J. Hydrogen Energy 2016, 41, 21990-21999. [CrossRef]

63. Liu, X.; Men, Y.; Wang, J.; He, R.; Wang, Y. Remarkable support effect on the reactivity of $\mathrm{Pt} / \mathrm{In}_{2} \mathrm{O}_{3} / \mathrm{MOx}$ catalysts for methanol steam reforming. J. Power Sources 2017, 364, 341-350. [CrossRef]

64. Bossola, F.; Scotti, N.; Somodi, F.; Coduri, M.; Evangelisti, C.; Dal Santo, V. Electron-poor copper nanoparticles over amorphous zirconia-silica as all-in-one catalytic sites for the methanol steam reforming. Appl. Catal. B Environ. 2019, 258, 118016. [CrossRef]

65. Vetrivel, S.; Neuberg, S.; Zapf, R.; Pennemann, H.; Kolb, G. Hydrogen production over highly active Pt based catalyst coatings by steam reforming of methanol: Effect of support and co-support. Int. J. Hydrogen Energy 2020, 45, 1658-1670. [CrossRef]

66. Dancini-Pontes, I.; DeSouza, M.; Silva, F.A.; Scaliante, M.H.N.O.; Alonso, C.G.; Bianchi, G.S.; Neto, A.M.; Pereira, G.M.; FernandesMachado, N.R.C. Influence of the $\mathrm{CeO}_{2}$ and $\mathrm{Nb}_{2} \mathrm{O}_{5}$ supports and the inert gas in ethanol steam reforming for $\mathrm{H}_{2}$ production. Chem. Eng. J. 2015, 273, 66-74. [CrossRef]

67. Tahir, M.; Mulewa, W.; Amin, N.A.S.; Zakaria, Z.Y. Thermodynamic and experimental analysis on ethanol steam reforming for hydrogen production over Ni-modified $\mathrm{TiO}_{2} / \mathrm{MMT}$ nanoclay catalyst. Energy Convers. Manag. 2017, 154, 25-37. [CrossRef]

68. Tran, S.B.T.; Choi, H.; Oh, S.; Park, J.Y. Defective $\mathrm{Nb}_{2} \mathrm{O}_{5}$-supported Pt catalysts for $\mathrm{CO}$ oxidation: Promoting catalytic activity via oxygen vacancy engineering. J. Catal. 2019, 375, 124-134. [CrossRef]

69. Wang, Y.; Li, D.; Li, K.; Farrauto, R. Enhanced propane and carbon monoxide oxidation activity by structural interactions of $\mathrm{CeO}_{2}$ with $\mathrm{MnO}_{x} / \mathrm{Nb}_{2} \mathrm{O}_{5-\mathrm{x}}$ catalysts. Appl. Catal. B Environ. 2020, 267, 118363. [CrossRef]

70. Lin, M.; An, B.; Takei, T.; Shishido, T.; Ishida, T.; Haruta, M.; Murayama, T. Features of $\mathrm{Nb}_{2} \mathrm{O}_{5}$ as a Metal Oxide Support of Pt and Pd Catalysts for Selective Catalytic Oxidation of $\mathrm{NH}_{3}$ with High $\mathrm{N}_{2}$ Selectivity. J. Catal. 2020, 389, 366-374. [CrossRef]

71. Kulkarni, A.K.; Panmand, R.P.; Sethi, Y.A.; Kadam, S.R.; Tekale, S.P.; Baeg, G.-H.; Ghule, A.V.; Kale, B.B. In situ preparation of N doped orthorhombic $\mathrm{Nb}_{2} \mathrm{O}_{5}$ nanoplates/rGO composites for photocatalytic hydrogen generation under sunlight. Int. J. Hydrogen Energy 2018, 43, 19873-19884. [CrossRef]

72. Tahir, M.; Amin, N.A.S. Indium-doped $\mathrm{TiO}_{2}$ nanoparticles for photocatalytic $\mathrm{CO}_{2}$ reduction with $\mathrm{H}_{2} \mathrm{O}$ vapors to $\mathrm{CH}_{4}$. Appl. Catal. B Environ. 2015, 162, 98-109. [CrossRef]

73. Stenina, I.A.; Voropaeva, E.Y.; Yaroslavtsev, A.B.; Veresov, A.G.; Kapustin, G.I. Effect of precipitation pH and heat treatment on the properties of hydrous zirconium dioxide. Rus. J. Inorg. Chem. 2008, 53, 350-356. [CrossRef]

74. Takezawa, N.; Iwasa, N. Steam reforming and dehydrogenation of methanol: Difference in the catalytic functions of copper and group VIII metals. Catal. Today 1997, 36, 45-56. [CrossRef] 